in a smaller number of subjects, but so framed as to prevent exclusive concern with two or three subjects over a long period. Here agreement and co-operation between universities rather than uniformity is required.

The Association's criticism of degree courses is that too many students specialize who are not fitted for the most advanced specialist work, and that the best students need a broader basis. It proposes a common course in the first year or two, followed by full specialization for those suited by ability and bent, and extension of the normal university course to four years once the post-war rush is over, with a much larger entry for the general degree course. Again, in regard to appointment boards, these should be bodies on which university teachers meet employing bodies to exchange information and to consult together on the relations between education and employment.

Dr. D. R. Pye, opening a discussion on research, using the word in its widest sense as giving vitality to teaching, pointed out that while it cannot be expected that all members of a university staff will remain productive in research, much good would result from closer association between universities and the research staffs both in Government establishments and in industry, and he referred to the value of university lectures by research workers on their special subjects as a stimulus to post-graduate research groups in the universities. Also it must be possible for the universities to pay salaries which are adequate to retain the men who are capable of effective research and of training recruits in research; the number of such men must be sufficient to prevent them from being overburdened with teaching.

The closer association of the universities with industry presents special difficulties in the engineering faculties. Here, except in the borderland of physics and engineering, and especially towards the physical side, effective research is difficult to arrange at the universities, and it will always be difficult for the university work to keep in touch with changing technique. Accordingly, Dr. Pye welcomed the encouragement of local contacts with industry. $\mathrm{He}$ deprecated too close inquiry as to whether research is pure or applied: freedom in planning and in execution are pre-requisites for research which is worth while, but a fairly definite goal is no bad thing for the majority.

Prof. S. Brodetsky, opening the third discussion, on salaries, superannuation and representation of academic staff and academic council of the universities, said that a considerable increase in the staffs of universities is clearly necessary as well as a new scale of salaries, but he appeared to be opposed to the establishment of further research fellowships as recommended in the Association's Report. In regard to the new scale of salaries suggested, he emphasized, the desirability of discontinuing the so-called "Grade IV" appointments, and, secondly, that lecturers should reach a reasonable salary by about the age of forty. The Report proposes a salary of $£ 800$ to be reached by annual increments, following a probationary period, at about that age. Higher appointments, such as Grade I lecturers or readers, should similarly rise to $£ 1,100$, non-professorial heads of departments to $£ 1,300$, and for professors a basic salary of $£ 1,500$ is suggested. With regard to superannuation, a special Government grant is called for to put on a reasonable level members of university staffs of long service.
Prof. Brodetsky. also directed attention to the importance of university teachers taking a proper place in the administration of the universities, and to the recommendations in the Association's Report that university councils should include a fair representation of the university staff, both professorial and non-professorial. Each university should have permanent academic committees dealing with the question of development and other problems, while in connexion with regional universities special thought must be given to the place that graduates should occupy in their development and government. Finally, referring to the relations between the universities, he explained the reasons why the Association's Report recommended the establishment of an academic council of the universities to facilitate consultation and the work both of the University Grants Committee and the informal Vice-Chancellors' Committee.

The summer meeting of the Central Council of the Association of University Teachers took place on June 9 and 10 at the University of Birmingham. Forty-five members were present, representing the local associations in the various university institutions of England and Wales. The action of the University of Birmingham in making a gift of $£ 100$ to the University Books for China Fund, following an appeal made by Prof. E. R. Dodds, of the University of Oxford, who had recently returned from a visit to Chinese universities, was brought to the notice of members in the hope that other university institutions might feel able to help in a similar manner. A report was made regarding the conference of representatives of university governing bodies and members of the executive committee of the Association which took place on June 2 (see above). A Conference Committee was appointed to arrange for a series of conferences with, among others, school teachers and professional, technical and industrial organizations, the National Union of Students, etc., to consider specific problems arising out of the report. Copies of a booklet on "Health and the Student", issued by the National Union of Students, were before the meeting and, after consideration, it was agreed that it was desirable to support the efforts of the Union in this direction, and to recommend local branches to raise the whole question of student health (including medical care and welfare, living conditions and recreative facilities) with their governing bodies. The election of officers for the session 1944-45 was proceeded with, Prof. Roy Pascal of the University of Birmingham being appointed president.

\section{A FLATWORM PARASITE OF FRESHWATER TROUT}

$I^{\mathrm{N}}$ NVESTIGATING the cause of the deaths of practically 100 per cent of the freshwater trout in an open storage reservoir in South Wales in 1942, J. B. Duguid and Edith M. Sheppard (J. Path. and Bact., 56, 73; 1944) found that they were due to general peritonitis caused by the plerocercoids of a tapeworm belonging to the family Diphyllobothridæ. Hundreds of these flatworms, $1-10 \mathrm{~cm}$. long, were found burrowing in the peritoneal tissues. The sticklebacks (Gasterosteus aculeatus) in the same reservoir were also infested. 
The reservoir supplies domestic water and stands next to a suburban area, and is fed with filtered and chlorinated water conveyed by a closed pipe from reservoirs 25 miles away. A second smaller reservoir, separated only by a narrow embankment from the one in which the fish died, is used for industrial purposes and is fed from local streams. Both are stocked with trout and have been open to anglers for years. Apparently there have been no earlier outbreaks of disease in this reservoir. Many trout from other sources, including the supply reservoir 25 miles distant, were examined, but the cestode was not found in them, until, in March 1943, it was found in trout from the second smaller reservoir.

When the plerocercoids were fed to laboratory rats and to one dog, they developed into adult worms which resembled Diphyllobothrium latum, the 'broad tapeworm' of man. On the other hand, when they were implanted into the subcutaneous tissues and peritoneal cavities of rats, they did not multiply, but were encapsuled by fibrous tissue, remaining alive for three weeks. Identification of the species of the family Diphyllobothridæ is difficult, because only one stage in the life-histories of so many of them is known. The identity of the species found in these trout with $D$. latum of man has not yet been fully established. The adult, the egg, the coracidium and procercoid seem to correspond with those of $D$. latum, but the plerocercoids do not ; they seem to correspond with the descriptions given of Dibothrium cordiceps, which caused epidemies in trout in one of the Yellowstone Park Lakes. Similar epidemics have occurred in Elk Lake, Oregon and in California. Some helminthologists regard $D$. cordiceps as being identical with $D$. latum; others do not.

The authors' further work on the identity of this parasite will be awaited with interest, because $D$. latum is recorded in the British Isles only from the west of Ireland. To this record, Duguid and Sheppard add the Shetland Islands, where it is, they conclude from material supplied to them by Dr. Peterson of Yell, endemic among the freshwater trout of certain areas. D. latum is described as being cosmopolitan by some authorities, but the most important foci of it are all around the Baltic Sea, some of the Lakes of Switzerland and Italy, Bavaria, Hungary, the Danube delta, Poland and Rumania; it is also common in Turkestan and parts of Siberia and Japan, and foci are known in Africa. Its definitive hosts, apart from man, include the dog, eat, pig and various aquatic and terrestrial carnivores. It requires two intermediate hosts, a freshwater copepod and a freshwater fish (perch, pilke, salmon trout, etc.). The Cyclopidæ Diaptomus gracilis and Cyclops strenuus are commonly the crustacean hosts, and Duguid and Sheppard describe the life history of the South Wales species in these two copepods. They had not, at the time of writing, infested fish by feeding them with infested copepods. Nor could they explain how the parasite got into this carefully protected reservoir. They found little evidence that birds (for example, the gull) brought it there; it seemed more likely that a small mammal was the carrier. One Belgian soldier, who was later found to be a carrier of $D$. latum, had camped in the neighbourhood.

Commenting on this paper, The Lancet (April 8, p. 475 ) points out that $D$. latum has been introduced by immigrants into the United States, and suggests the possibility that it may have been brought to Great Britain by refugees from Norway or Poland.

G. LAPAGE.

\section{APPOINTMENTS VACANT}

APPLICATIONS are invited for the following appointments on or before the dates mentioned :

LABORATORY ATTENDANT IN THE DEPARTMENT OF ORGANIO ChEMrstrY - The Secretary, Bedford College for Women, Regent' Park, London, N.W.1 (August 9)

GRADUATE LECTURER (full-time) for GRograpHY in the Newport Technical College-The Director of Education, Education Offices Charles Street, Newport, Mon. (August 11).

SPEECH THERAPIST-The Chief Education Officer, West House Halifax (August 12).

SPEECH THERAPIST-The Director of Education, Stanley Buildings, Caunce Street, Blackpool (August 12).

AssistaNT PHYSICIST to the Sheffield Radium Centre-The Secretary, heffield Radium Centre, Royal Infirmary, Sheffield 6 (August 12). BIOLOGIST at the West Midland Forensic Science Laboratory at Birmingham-The Establishment Officer, Room 320, Home Office, Whitehall, London, S.W.1 (August 12).

Assistant LECTURBR IN METALLURGY-The Acting Registrar, The University, Leeds 2 (August 12).

CHIEF MFTallurgical CHEMist with established Midland firm to take charge of Laboratory, Chemical Control of Production, and Experimental Research work in connexion with Powdered Metals, etc. -The Ministry of Labour and National Service, Boom 432, Alexandra (August 14).

ELECTRICAL ENGINEER by the Tanganyika Territory Government Labour Department-The Ministry of Labour and National Service, Room 432, Alexandra House, Kingsway, London, W.C.2 (quoting Reference No. D.904A) (August 14).

AsSisTaNT MASTER to teach SoIENCR SUBJECTs at the Fxeter Junior Technical School-The Director of Education, City Education Offices, 33 St. David's Hill, Exeter (August 14).

SPEECH THERAPIST (female)-The Director of Education, Huntriss Row, Scarborough (August 14).

ANTI-MALARIAL ENGINERR by the Government of Fiji-The Ministry of Labour andNational Service, Room 432, Alexandra House, Kingsway, London, W.C.2 (quoting Reference No. E.1082A) (August 14). GRADUATE ASSISTANT MASTER t $d$ teach PHYSICS AND ENGINEERING Education, Higher Education Department, County Hall, Newport Mon. (August 15).

Mon. (August 15). EDUCATrONAL PSYCHOLOGIST, and a PSYCHIATRIC SOCIAL WORKER Sick Children, 180 Falls Road, Belfast (August 15).

Sick Children, 180 Falls Road, Belfast (August 15).
LECTURER IN MECHANICAL ENGINEERING OR M.ATHEMATIOS at the LECTURER IN MECHANICAL ENGINEERING OR M.ATHEMATICS at the
Monmouthshire Mining and Technical College, Crumlin-The Director of Education, Higher Education Department, County Hall, Newport, of Education, High

GENERATION ENGINEER-The Borough Electrical Engineerand ManGENERATION ENGINEER-The Boroug
เger, Guildhall, Swansea (August 19).

iger, Guildhall, Swansea (August 19). ASSISTANT LECTURER (temporary) in
University College, Exeter (August 19).

University College, Exeter (August 19). PRINCIPAL OF THE ROYAL TECHNICAL COLLEGE, Salford-The
Correspondent to the Governors, Education Offices, Chapel Street, Salford 3, Lanes. (August 21)

BOROUGH ENGINERR AND SURVEYOR to the County Borough of Southampton-The 'Town Clerk, Town Clerk's Offlce, Civic Centre, Southampton (endorsed 'Borough Engineer and Surveyor') (September 4).

Borough Engrnekr and SURveyoR-The Town Clerk, Town Hall, West Ham, London, E.15 (endorsed 'Borough Engineer and Surveyor') (September 4).

UNIVERSITY READRRSHIP IN PHysics tenable at King's CollegeThe Academic Registrar, University of London, c/o Richmond College, Richmond, Surrey (September 6).

CHAIR of MINING-The Acting Registrar, The University, Leeds 2 September 30).

LECTURER IN PHILOsOPHY-The Very Rev. the Dean, Christ Church, Oxford (October 15).

PROFESSOR OF PHYsICs-The Registrar, University College, Singleton Park, Swansea.

LECTURER IN ELECTRICAI ENGINEERING with special reference to design of Eleotrical Machinery-The Principal, Faraday House Electrical Engineering College, 62-70 Southampton Row, London, W.C.1.

Lecturer in Mrohanical Engineming for teaching Senior and Junior Day and Evening Students, and a LECTURER IN CHEMIrSTRY with subsidiary Mathematics, Physics or Biology-The Principal, Municipal College, Victoria Circus, Southend-on-Sea.

\section{REPORTS and other PUBLICATIONS}

(not included in the monthly Books Supplement)

\section{Great Britain and Ireland}

British Rubber Producers' Research Association. Publication No.46: Strains in an Inflated Rubber Sheet, and the Mechanism of Bursting. By Dr. L. R. G. Treloar. Pp. 12. Publication No. 47: The Structure and Elasticity of Rubber. By Dr. L. R. G. Treloar. Pp. 24. Publication. No. 48: Rubber, Polyisoprenes and Allied Compounds, Part 6: The Mechanism of Halogen-substitution Reactions, and the Additive Halogenation of Rubber and of Dihydromyrcene. By, George F. Bloomfield. Pp. 8. (London: 'British Rubber Producers'
Research Association.) Royal. Society for the Protection of Birds. Fifty-third Annual Royal Society for the Protection of Birds. Fifty-third Annual
Report, January 1st to December 31 st, 1943, with Proceedings of Report, January 1st to December 31 st, 1943, with Proceedings of
Annual Meeting, 1944. Pp. 48. (London: Royal Society for the Annual Meeting, 1944. Pp. 48. (London: Royal Society for the
[147 